\title{
PENGOLAHAN DAN PENYAJIAN MAKANAN NEGARA MALAYSIA
}

\author{
Dikki Zulfikar \\ Program Studi Pendidikan Kesejahteraan Keluarga \\ Fakultas Pariwisata Dan Perhotelan \\ Universitas Negeri Padang \\ email : dikkizulfikar@fpp.unp.ac.id
}

\begin{abstract}
Abstrak
Malaysia adalah negara yang memiliki keragaman budaya yang plural dan heterogen. Malaysia merupakan negara persemakmuran Inggris yang memiliki keragaman etnis, agama, dan budaya. Malaysia dan Indonesia merupakan saudara satu rumpun yang memiliki banyak persamaan. KeanekaragamanKeanekaragaman etnis, agama, dan budaya merupakan sedikit bentuk persamaan antara Malaysia dengan Indonesia. MasyarakatMasyarakat Malaysia identik dengan sebutan "orang Melayu". Padahal bukan hanya Malaysia yang merupakan orang Melayu, Indonesia juga merupakan orang Melayu, dan negara-negara di Asia Tenggara juga merupakan orang Melayu. Mengapa harus ada sebutan "orang Melayu" bagi warga Malaysia? Padahal bukan hanya Malaysia yang merupakan orang Melayu. Ini semua karena faktor sejarah dan budaya yang ada di Malaysia. Sedikit berbeda dengan di Indonesia yang terdiri dari banyak etnis yang beranekaragam. Masyarakat Malaysia sudah lama mengakui bahwa minimal ada empat golongan etnis di Malaysia, yaitu etnis Melayu, Cina, India, dan penduduk asli yang bertempat tinggal di Sabah dan Serawak. Dengan kata lain, di Malaysia, masyarakat tidak terlalu dipusingkan dengan perbedaan etnis yang ada. Identitas tiap etnis yang berbeda pun dapat dengan mudah diterima dalam kehidupan bermasyarakat di Malaysia.adapun hidangan khas masyarakat Malaysia yaitu nasi lemak.
\end{abstract}

Kata kunci: Pengolahan Makanan Malaysia, Penyajian Makanan Malaysia, Makanan Khas Malaysia 


\section{Pendahuluan}

Bahasa resmi: Malaysia (resmi); Inggris; Cina (Kanton, Mandarin, Hokkien, Hakka, Hainan, Foochow); Tamil; Telugu; Malayalam; Panjabi; Thai.Ibukota: Kuala Lumpur ,Luas wilayah (km2): 329.750 ,populasi Malaysia per 2005 adalah 25.580.000. Bahasa resminya Melayu dan Inggris.Agama yang dianut para penduduk adalah Islam $(60,4 \%)$, Buddha $(19,2 \%)$, Kristen (9,1\%),Hindu (6,3\%), Konghucu/Tao/Agama Cina lainnya (2,6\%),agama lainnya $(2,4 \%)$. Komposit etnisnya Melayu dan asli melayu lainnya $(65,1 \%)$, Cina $(26 \%)$, India $(7,7 \%)$, lainnya (1,2\%).Malaysia terletak di 2 wilayah terpisah. Satu di barat di ujung semenanjung Malaya. Satu di timur yaitu di pulau Kalimantan (Indonesia). Di malaysia barat, utara berbatasan dengan Thailand, selatan dengan selat Malaka dan Selat Singapura, barat dengan Selat Malaka, dan timur dengan wilayah laut Cina Selatan. Di Malaysia timur, utara berbatasan dengan Laut Cina Selatan, selatan dengan Indonesia, barat dengan Laut Cina Selatan, dan Timur dengan Laut Sulu. Batas darat dengan Brunei sepanjang 381 km, dengan Indonesia 2004 km, dan dengan Thailand $506 \mathrm{~km}$. Garis pantai Malaysia adalah $4675 \mathrm{~km}$. Penduduk: 29.628.392 orang.Etnis: Melayu 50,4\%; Cina 23,7\%; asli 11\%; India 7,1\%; lainnya 7,8\%.Agama: Islam (resmi) 60,4\%; Buddha 19,2\%; Kristen 9,1\%; Hindu 6,3\%; Konfusian; Tao; agama tradisional Cina lainnya 2,6\%; lainnya 1,5\%; tidak beragama 0,8\%. Jenis kekuasaan: Monarki Konstitusional ---- [Modelnya mirip Inggris]

Berasal dari hasil observasi Masakan Malaysia mencerminkan solekan pelbagai etnik penduduknya,dan ditakrifkan oleh kepelbagaiannya.Banyak budaya dari Malaysia dan kawasan sekitarnya telah banyak mempengaruhi masakan Malaysia, dengan pengaruh yang kuat dari masakan Melayu, Cina, India, Thailand, Jawa dan Sumatera.Kebanyakannya adalah kerana Malaysia menjadi sebahagian daripada laluan rempah kuno.Masakan ini sangat mirip dengan Singapura dan Brunei,dan juga mempunyai persamaan dengan masakan Filipina.Negeri-negeri yang berlainan di Malaysia mempunyai pelbagai hidangan,dan selalunya makanan di Malaysia berbeza dari hidangan asal.

Kadang-kadang makanan yang tidak dijumpai dalam budaya asalnya diasimilasikan ke dalam yang lain; Sebagai contoh, restoran Cina di Malaysia sering memberi hidangan Malaysia.Makanan dari satu budaya kadang-kadang dimasak dengan menggunakan gaya yang diambil dari yang lain.Ini bermakna walaupun banyak hidangan Malaysia berasal dari budaya lain, mereka mempunyai identiti mereka sendiri.Selalunya makanan di Malaysia adalah berbeza dari hidangan asal. Sebagai contoh, makanan Cina sering lebih manis dalam versi 
Malaysia daripada yang asal.Peranakan, orang Cina yang berpindah ke Malaysia berabad-abad yang lalu, mempunyai masakan unik mereka yang menggunakan teknik memasak Cina dengan bahan-bahan Melayu.

Semasa makan malam tidak disampaikan dalam bentuk sajian, tetapi semuanya sekaligus.Beras popular di banyak hidangan Malaysia. Cili biasanya terdapat dalam hidangan Malaysia, walaupun ini tidak menjadikan mereka pedas. Mi adalah perkara biasa. Daging babi jarang digunakan di Malaysia, kerana penduduk Islam yang besar. Beberapa perayaan mempunyai makanan yang berkaitan dengan mereka, dan kuih bulan sering dimakan ketika Festival Kuih Bulan.

\section{Metodologi penelitian}

Jenis penelitian ini adalah kualitatif.fokus penelitian adalah makanan khas dan cara penyajian dan tata cara makan orang malaysia.teknik dalam mengumpulkan data dikumpulkan dengan mengkaji dengan sumber literatur

\section{Pembahasan}

\section{Tata cara penyajian makanan Malaysia}

Ketika berkunjung ke rumah orang, apabila tuan menghidangkan makanan atau minuman, janganlah menolaknya. Jika kenyang sekalipun kita hendaklah setidak-tidaknya menjamah sedikit hidangan yang disajikan itu.Setelah makanan dihidangkan, pastikan orang yang lebih tua duduk dahulu kemudian baharulah diikuti oleh orang muda pula mengambil tempat masing-masing.Anak gadis pula dikehendaki menyenduk nasi ke dalam pinggan orang yang lebih tua.Biarkan orang yang lebih tua mengambil makanan dahulu kemudian barulah diikuti oleh orang muda. Adalah tidak sopan jika membiarkan orang yang lebih tua makan sisa orang muda. Oleh itu, sesetengah orang membuat peraturan supaya orang muda makan berasingan daripada orang yang lebih tua atau orang tua makan dahulu daripada orang muda. Bagaimanapun, amalan ini tidak begitu sesuai jika hendak menanamkan kemesraan dan semangat kekeluargaan dalam kalangan anak-anak.Ketika makan seelok-eloknya ambillah makanan yang berhampiran dengan kita. Janganlah menjangkau makanan yang sukar dicapai. Mintalah bantuan orang lain yang berdekatan jika kita mahukan makanan itu.Ketika menghulur atau menyambut makanan, sebaikbaiknya gunakan tangan kanan, tetapi jika tangan kanan kotor, bolehlah kita menggunakan tangan kiri.Semasa menghulur dan menyambut makanan, seelok-eloknya siku atau pergelangan tangan ditampung sedikit dengan tangan yang sebelah lagi.Semasa mengambil 
kuah atau nasi, gunakan tangan kiri supaya sudu atau senduk tidak kotor.Pastikan sudu, piring atau mangkuk tidak berlaga dan berbunyi ketika menyenduk. Ini dianggap kurang sopan dan kasar jika berlaku pergeseran antara sudu, piring atau mangkuk sehingga berbunyi.Ketika makan pula janganlah bercakap-cakap. Lebih-lebih lagi jika mulut penuh dengan makanan. Jika bercakap pun pastikan tidak menimbulkan perkara yang kurang menyenangkan sehingga boleh mengganggu selera makan orang lain. Jangan makan berbunyi, umpamanya menghirup minuman atau mengunyah makanan. Ketika orang lain sedang makan janganlah menghembus hingus, berkahak atau berludah dengan makan. Jangan makan terlalu kenyang. Makanlah setakat mengenyangkan atau mengalas perut sahaja.Jika selesai makan terlebih dahulu jangan sekali-kali mengangkat pinggan dan meninggalkan orang yang sedang makan. Seelok-eloknya tunggu dan pastikan semua orang sudah selesai makan barulah bangun. Jika mahu mengemaskan tempat makan atau meja makan, pastikan semua orang sudah selesai makan. Tidak sopan jika mengemas ketika orang lain masih menikmati hidangan. Jika dilakukan, seolah-olah kita menyindirya supaya berhenti makan atau melarangnya menghabis makanannya. Jangan pergi ke rumah orang pada waktu makan dan waktu maghrib. Ini mengganggu tuan rumah kerana mungkin dia telah memasak makanan cukup untuk keluarganya sahaja. Waktu maghrib pula adalah waktu sembahyang yang paling singkat dan kedatangan tetamu menyebabkan tuan rumah serba salah untuk meninggalkan tetamu keseorangan. Oleh itu seelok-eloknya datanglah selepas waktu isyak.Pantang larang ini diadakan bukan sahaja sebagai pengajaran tetapi bertujuan untuk menjaga tatasusila supaya kita tidak melakukan perkara yang kurang sopan. Orang Melayu memang terkenal dengan sopan santun mereka sejak zaman dahulu lagi. Oleh yang demikian, beberapa pantang larang diwujudkan supaya kesopanan dapat dikekalkan hingga ke generasi yang akan datang.

\section{Alat yang digunakan untuk mengolah oleh masyarakat Malaysia}

Kehidupan masyarakat Melayu juga tidak dapat melepaskan diri dari peralatan rumah tangga, terutama peralatan dapur atau peralatan masak-memasak. Peralatan rumah tangga khas Melayu yang pernah dipakai atau masih dipakai, antara lain :Periuk (periuk bertutup, periuk gerenseng, periuk tanah, dan periuk bertutup bertelinga dua),Kuali, dan belanga. Alat-alat ini secara umum digunakan untuk memasak masakan sehari-hari, namun, ada juga alat memasak ini yang digunakan secara khusus, misalnya belanga dan periuk tanah. Belanga digunakan untuk memasak gulai dan periuk tanah digunakan untuk merebus 
obat-obatan.Lesung batu, nyiru,Ayak, tapis(an),Sudip, sendok, sudu,Kukur kelapa.Tudung saji,Lekar, talam,Ceret (ceret memiliki beberapa macam, seperti tekoh, torak atau kendi, ceret labu, labu duduk).adapun alat modern yang dipakai orang Malaysia pada umumnya sama hanya bentuknya saja yang berbeda.

\section{Bumbu dan rempah dari Malaysia}

Sebenarnya bumbu dan rempah Malaysia hampir semua mirip, hanya saja bagaimana kita mengolahnya,disini ada beberapa contoh: cengkeh,lada,kayu manis,pala,kapulaga, kunyit,ketumbar,daun salam,jahe,serai, dll.

\section{Makanan khas negara Malaysia}

Kuliner Nasi Lemak,Makanan khas Malaysia yang berada di urutan pertama adalah nasi Lemak. Hal ini karena kuliner ini merupakan makanan khas Malaysia yang sudah sangat melekat dengan citra Malaysia. Ketika anda naik pesawat AirAsia misalnya, menu favoritnya adalah nasi Lemak. Ini karena AirAsia adalah maskapai yang berasal dari Negara Malaysia.Populernya nasi lemak ini di kalangan wisatawan mancanegara membuatnya sempat dibukukan dalam karya Sir Richard Olaf Wlnstedt dalam bukunya yang berjudul The Circumstances of Malay.Kata Lemak dari nasi Lemak merujuk pada rasa yang gurih karena nasi ini mengandung lemak nabati dan santan kelapa yang membuat rasanya menjadi nikmat. Kuliner khas ini meliputi kawasan Sumatra Utara khususnya Aceh, sehingga anda pun akan menemukan kuliner ini di daerah tersebut. Bukan hanya itu, Singapore dan Brunei juga sering menghidangkan kuliner ini walaupun dengan cita rasa yang berbeda.Untuk pembuatan nasi lemak ini sendiri dibuat menggunakan santan dan ditambahkan daun pandan saat ditanak. Hal ini menghasilkan nasi yang berlemak dan beraroma gurih. Dalam penghidangannya, nasi lemak biasanya disajikan dengan lauk tahu tempe, telur, ikan teri. Dan kadangkala dikreasikan dengan menambahkan cumi, udang, petai kacang panjang, ayam, atau ikan bilis.

\section{Simpulan dan saran}

\section{Simpulan}

Masakan Malaysia mencerminkan solekan perbagai etnik penduduknya,dan ditakrifkan oleh keperbagaiannya. Banyak budaya dari Malaysia dan kawasan sekitarnya telah banyak mempengaruhi masakan Malaysia, dengan pengaruh yang kuat dari masakan Melayu, Cina, India, Thailand, Jawa dan Sumatera.Kebanyakannya adalah kerana Malaysia menjadi sebahagian daripada laluan rempah kuno.Masakan ini sangat mirip dengan Singapura dan Brunei,dan juga mempunyai persamaan dengan masakan Filipina.Negeri-negeri yang 
berlainan di Malaysia mempunyai pelbagai hidangan,dan selalunya makanan di Malaysia berbeda

\section{Saran}

Menyadari bahwa penulis masih jauh dari kata sempurna, kedepannya penulis akan lebih fokus dan details dalam menjelaskan tentang makalah di atas dengan sumber - sumber yang lebih banyak yang tentunga dapat di pertanggung jawabkan. Untuk saran bisa berisi kritik atau saran terhadap penulisan juga bisa untuk menanggapi terhadap kesimpulan dari bahasan makalah yang telah di jelaskan. Untuk bagian terakhir dari makalah adalah daftar pustaka. Pada kesempatan lain akan saya jelaskan tentang daftar pustaka makalah.

\section{Daftar Pustaka}

Sari.2007: Jurnal Institut Bahasa, Kesusateraan dan Kebudayaan Melayu, Universiti Kebangsaan Malaysia, Volumes 5-10

S Nik Shanita, H Hasnah, CW Khoo Sains Malaysiana 40 (8), 865-870, 2011

Silfeni.1989.Pengolahan dan Penyajian Makanan Oriental. PKK FT UNP

Zifanhea, crhisterra (2007) rempah rahasia yang bikin masakan sedap.Kuala Lumpur: MDC Publishers \& Printers Sdn Bhd, 2002

Zulfikar, D. (2018, October 17). Pengembangan Media Pembelajaran Video Tutorial Berbahasa Inggris Pengolahan Makanan Kontinental Pada Sekolah Menengah Kejuruan Program Keahlian Jasa Boga. Retrieved from osf.io/k6e5z 
